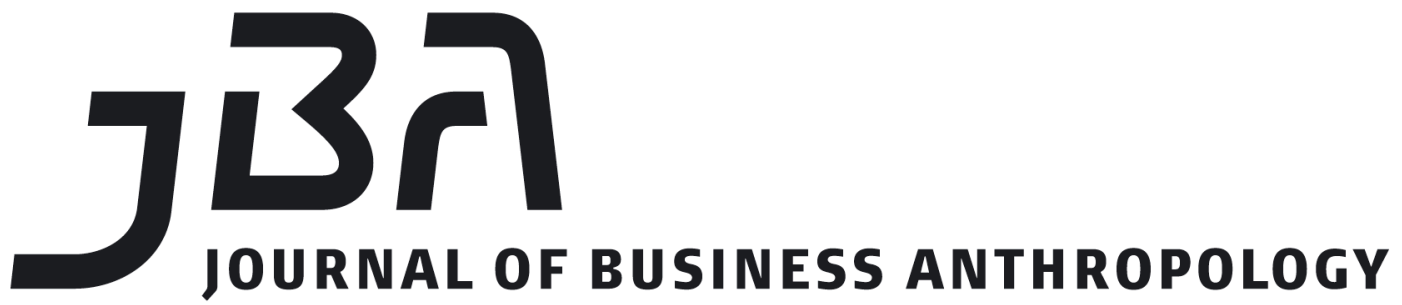

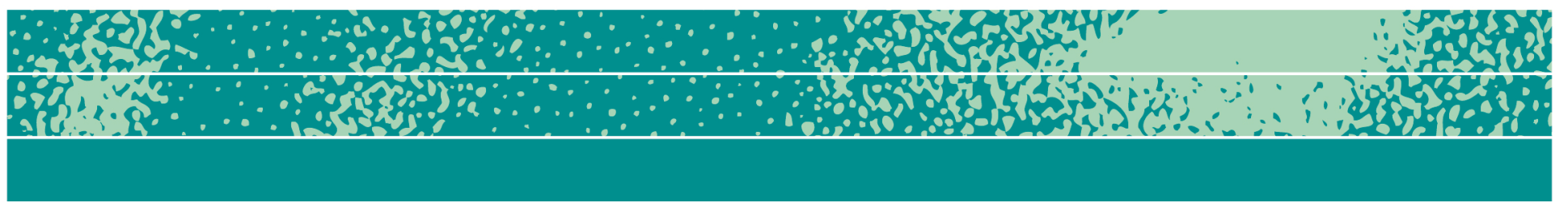

\section{Unfair Trade: Protectionism, Protests and the Pursuit of Free Trade in New Zealand}

\author{
Sasha Maher
}

\begin{abstract}
Is free trade dead? In January 2017, President Trump withdrew the United States from the controversial Trans-Pacific Partnership free trade agreement (TPP). This paper examines some of the anthropological implications of what emerged out of the "death" of the TPP. It analyses what this reveals about the changing contours of the neoliberal state, business-government relations and the subjectivity of corporate leaders. More broadly, it seeks to explain the tenacity of free trade and what is at stake in pursuing free trade agreements such as the TPP. Drawing on fieldwork among state and business elites in New Zealand, the paper suggests that rather than rethink its policy direction, the state deployed discursive strategies and elicited the help of business to reposition free trade as the solution, not the cause that eventually "killed" the TPP. Thus, rather than undermine neoliberalism, the demise of the TPP opened the possibility of its advancement.
\end{abstract}

\section{Key words}

Free trade, neoliberalism, New Zealand, business, elites 


\section{Introduction}

With a stroke of a pen on 23 January 2017, President Trump pulled the United States out of the disputed Trans-Pacific Partnership free trade agreement (TPP) ${ }^{1}$, exclaiming, "A great thing for the American Worker we just did."2 State officials, politicians and corporate elites, key proponents of the TPP, cited Trump's action as short-sighted and devastating for the economic growth and pacification of the Asia Pacific region. ${ }^{3}$ The "death" of the TPP was lamented as untimely. Its critics, on the other hand, celebrated this as a victory of "the People's Movement, not Trump" and as "one of the many signs that this limb of the neoliberal paradigm is in crisis." 4 Taking the TPP's apparent demise as a starting point, this paper investigates what emerged from Trump's withdrawal. But whereas most commentary has centred on how to reform the agreement,5 I instead attempt to uncover what kinds of discursive work Trump's decision ushered in.

As I intend to demonstrate in a case centred on New Zealand, in response to mounting opposition against its trade policy approach, the government repositioned free trade as the solution to criticism, not the cause. In doing so, the state momentarily rescued free trade and the highly controversial TPP from the threat of deeper attacks while entrenching the prevailing orthodox view of free trade agreements (FTAs) as unquestionably rational and incontestable. To accomplish this, the government actively solicited the help of corporate leaders and business to defend and "perform" the policy (Hoffman 2007; Ong 2006). The government, in turn, retasked itself as the facilitator, the benevolent supporter of this endeavour, while business became "doubly responsibilized", "morally burdened agents", obliged to promote FTAs and grow the economy on behalf of other citizens (Brown 2015:134).

Opening an inquiry into why free trade remains "doxa" (Bourdieu

\footnotetext{
${ }^{1}$ In early 2018 the TPP was renamed the Comprehensive and Progressive Agreement for the Trans-Pacific Partnership (CPTPP), it was official signed by the original TPP parties (excluding the US) on March 8, 2018. In this article I will use the TPP because my analysis focuses on the time period before the name change.

${ }^{2}$ P. Baker. “Trump Abandons Trans-Pacific Partnership, Obama's Signature Trade Deal." New York Times, 23 January 2017, https://www.nytimes.com/2017/01/23/us/politics/tpp-trump-trade-nafta.html ${ }^{3}$ For example, R. Blackwell and T. Rappleye. “Trump's Five Mistaken Reasons for Withdrawing from the Trans-Pacific Partnership." Foreign Policy, June 22, 2017, http://foreignpolicy.com/2017/06/22/trumps-five-mistaken-reasons-forwithdrawing-from-the-trans-pacific-partnership-china-trade-economics/

${ }^{4}$ J. Kelsey “Trade Deal Dead and Major Rethink Needed." NZ Herald, 17 June 2017, http://www.nzherald.co.nz/nz/news/article.cfm?c id=1\&objectid=11749471

${ }^{5}$ For example, J. Schott. "TPP Could Go Forward without the United States." PIIE Blog (blog) 15 November 2016 https://piie.com/blogs/trade-investment-policywatch/tpp-could-go-forward-without-united-states
} 
and Eagleton 1992) despite pronounced protests requires us to consider several related factors. Most obviously, we must critically question the modalities through which neoliberal political reason continues to underpin trade policy. FTAs are the prized centrepiece of a neoliberal trade agenda, and so our analysis of free trade must include the cultural nature of FTAs. In order to explore what emerged from the TPP's ostensible moment of failure (Lea 2008; Miyazaki and Riles 2005; Riles 2004), I am guided by two bodies of interrelated literature. The first is the work from the anthropology of policy (Shore and Wright 1997, 2011), and the second is Foucauldian discussions of neoliberalism (Brown 2015; Ong 2006; Rose 1999).

I contribute to these studies and the anthropology of business in three main ways. Firstly, I examine the rarely considered subject of free trade from the perspective of elites (Shore and Nugent 2002) engaged or implicated in the making of trade policy as opposed to "local" people who are affected by free trade (Gledhill 1995, Gutmann 1998, Hewamanne 2008, Pearson 2013, Slocum 2006). This approach involves "studying up" (Nader 1974) in order to understand how power is produced through trade policy. Secondly my focus on free trade complements the existing literature on corporate social responsibility (CSR) (e.g., Besky 2016; Dolan and Rajak 2016; Fisher 2013, Lyon 2010, Moberg 2016; Smith and Helfgott 2010; Welker 2009) by inquiring into how FTAs are widening their scope to include sustainability and development concerns. Thirdly, I draw attention to the work of business elites in policymaking; a group often ignored in anthropology except for a few studies (Wedel 2004, 2009). By focusing on the policy work of business I also wish to highlight how the relationship between governments, state actors and business is historically specific and nuanced; although neoliberalism is a wellestablished mode of governance in New Zealand, it is the state not business which plays the dominant role in maintaining the status quo. An outcome of this is that FTAs are top-down initiatives, produced by powerful government agencies with business often lagging behind in both understanding and ability to influence negotiations. This is despite the observation that the rules and regulations made during trade negotiations significantly affect the internal workings of business.

This case study is based on over nine years of fieldwork from 2008 to the present. During this time, I have engaged in full-time and part-time forms of "non-local ethnography" (Feldman 2011: 45) on a loose network of pro-free trade New Zealand state and corporate elites. As well as carrying out participant observation in often transient settings, this has also involved gathering a wide variety of data from many sources: political speeches, policy statements, economic analyses, public diplomacy brochures, think tank reports, news feeds, blogs, legislation and FTA negotiation texts. These "bits and pieces of policymaking" (Wright and Reinhold 2011:27) have at times been complemented by in- 
depth interviews. The foundation of my fieldwork has been, and remains, participant observation. This has mostly comprised engaging with business leaders at diplomatic or business functions, fora, dinners and informal gatherings in hotels, bars and cafes. This approach to fieldwork is considered the most useful given that policy is produced neither at one site nor by one set of authors (Feldman 2005; Shore and Wright 2011). Although the account below centres on excerpts from speeches, blogs and official documents, my experience informs my insights (Hastrup 2005). However, I do not explicitly draw on these in this paper. Rather, my analysis centres on the delivery, form and implications of elite discourse.

New Zealand's self-designated status as a "firm supporter" and "champion" for free trade" 6 and its role as founding member and official depository ${ }^{7}$ of the TPP makes it an ideal entry point for analysing the tenacity of free trade. During the heated debates on the TPP, New Zealand became a nodal point of action both for and against the deal. Protestors and proponents alike were connected to separate networks of activism (Keck and Sikkink 2014) that spanned across the TPP countries. Although New Zealand provides the ethnographic material, however, this paper is not about the idiosyncrasies of New Zealand's "experiment" with neoliberalism (Kelsey 1995). Neither does it offer alternative approaches to conducting trade. ${ }^{8}$ Free trade discourse circulates beyond the boundaries of New Zealand and is strategically used at different times by various interest groups. My intention is, therefore, to not only detail New Zealand's response to a "mobile set of practices" (Ong 2007:4) but to also open our understanding beyond the purely economic to consider the wide-ranging repercussions of trade policies and discourses. Thus, I leave discussions about the costs and benefits of trade to others but do take note of this work (Kelsey 2008, 2010; Lewis 2005; Lim et al 2012; Petri and Plummer 2012).

Following a brief overview of my conceptual framework, I track the history of New Zealand's trade policy and map out the changes and continuities in policymaking from when New Zealand became a British colony in 1840 to its recent quest for the TPP. I suggest that the current neoliberal approach to trade is a very recent development and that since

\footnotetext{
${ }^{6}$ Ministry for Foreign Affairs and Trade. 30 April 2017, https://www.mfat.govt.nz/en/trade/nz-trade-policy/, 30 April 2017

${ }^{7}$ As the official depository, New Zealand is required to safeguard for four years after the last negotiating round: the negotiating texts, the proposals of each government, the accompanying explanatory material, the emails related to the substance of the negotiations, and any other information that was exchanged among the TPP countries in the context of negotiations.

${ }^{8}$ As Kelsey (1995) and Larner (2003) both note, the "New Zealand Experiment" was an extreme example of the application of a theoretical model. The package of reforms included inter alia market liberalisation, free trade, monetarist policy, fiscal restraint and the deregulation of the labour market.
} 
the late 1990s, domestic consensus has been tenuous. President Trump's decision and the TPP protests simply revealed this existing fragility. In the ethnographic section that follows, I give a detailed account of the launch of New Zealand's 2017 trade strategy document titled Trade Agenda: 2030 at a business-government function. In dialogue with Wendy Brown (2015), I use the speech delivered by Prime Minister Bill English as a platform to then analyse the strategy document and public diplomacy speeches and blogs by corporate leaders and politicians who are members of a pro-free trade network. In the conclusion, I return to the broader question of why free trade remains a compelling policy option.

\section{Opening the "Black Box"}

In conventional accounts of trade policy, FTAs are viewed mechanistically as economic instruments authored by rational state officials working in the "national interest" (e.g., Brawley 2005; Grossman and Helpman 2002; Krasner 1978). Trade policy has many technicalities, and much of the focus by proponents and critics alike is on the content of FTAs and the anticipated policy outcomes (e.g., Lim et al 2012; Kelsey 2010). The literature tends to concentrate on the economic, legalistic or geopolitical motivations and implications underlying FTAs (e.g., Kelsey 2010; Griffith et al 2015). How FTAs are made and by whom has also been debated in the literature but from either a narrow statist viewpoint (e.g., Krasner 1978, 2009; Krugman 1986; Krueger 1995; Skocpol 1985) or a societycentric viewpoint (e.g., Cox 1996; Milner 1997; Putnam 1988;

Schattschneider 1935; Olson 1995). In both versions, FTAs are rendered as economic objects set apart from society and culture (Mitchell 1999).

In contrast, I build on the anthropology of policy and neoliberalism to recast FTAs as discursive projects. These techniques strategically gather diverse discourses and align them to create a neoliberal mode of governance (Shore 2011). Drawing on anthropologists who focus on elites in policymaking, I try to explain how and to what effect elites produce policy rhetoric (Feldman 2005; Shore 2011). However, although most of the attention is concentrated on bureaucrats or experts (Greenhalgh 2008; Holmes 2009; Lea 2008; Schwegler 2008), mine focuses on business as well as state actors because FTAs are not the work of state officials alone. At various levels, they involve assistance from influential non-state actors. The closest resemblance to my work is Janine Wedel $(2004,2009)$ who has directly tackled the role of business interests in policy. In Shadow Elite, Wedel (Wedel 2009) argues that "state-private hybrids" called "flex-organisations" leverage their official connections to secure international aid money and newly privatised state assets in the former Soviet Union. Wedel's "flexi groups" are similar to the business-government network that informs this research.

In framing FTAs as techniques of governance, I am informed by 
Foucauldian interpretations of neoliberalism (Brown 2015; Ong 2006; Rose 1999). In particular, Wendy Brown's formulation of neoliberal political rationality sheds light on my findings. In Undoing the Demos: Neoliberalism as Revolution (2015), Brown draws on Foucault $(1978 / 1991)$ and Caliskan and Callon $(2009,2010)$ to argue that more than a suite of economic policies (see also Larner 2003) the core feature of neoliberalism is in how it "disseminates the model of the market to all domains and activities" and, in the process, reconfigures the "knowledge, form, content and conduct appropriate to these spheres and practices" (Brown 2015:31). She suggests that as neoliberalism recasts states and persons as firms, their duties and responsibilities are thereby reshuffled, and liberal democracy is undermined. Brown also extends the concept of the self-managed subject (Cruickshank 1993; Foucault 1978/1991; Rose 1999) to argue that individuals are not only made responsible for their own conduct, to be "governed at a distance", but are also tied to the fate the economy. People must share the pain of economic downturns by accepting austerity measures, precarious employment, stagflation, housing shortages and volatile consumer prices (Brown 2015: 210). No longer protected by the social contract, they must instead tolerate "insecurity, deprivation and extreme exposure to maintain competitive positioning, growth or credit rating of the nation as a firm" (213).

I draw on Brown's ideas and apply these to business leaders close to the state and policy-making process. I am interested in how the state seeks to involve business in the dissemination of neoliberal political rationality, that is, how and why it enjoins business to not only legitimise free trade in their conduct of cross-border transactions by "performing" the policy but also help to grow the "national economy" (Appel 2017) and advocate on its behalf for free trade. This is more than simply "bridling" or absorbing business in order to control and create political acquiescence (Pero 2011:224). Rather, it also involves the transformation of corporate actors from merely business owners, management or board members to "risk takers", "entrepreneurs" and "unofficial diplomats" (see Berman and Johnson 1977). In this regard, I follow Aihwa Ong's $(2006,2007)$ work in Neoliberalism as Exception (2006) to suggest that neoliberalism is not a "structural condition that projects totalizing social change" (2007:4) but that it strategically responds to populations and space (see Hoffman 2010). In New Zealand, the state, with help from chosen business elites, targeted business in order to make it responsible for helping to reinvigorate its trade agenda. Business, "globally" connected exporters in particular (Larner 2007; Tsing 2011), were applauded and afforded agency by the state as productive contributors to the economy. At the same time, "passive" participants or "non-agents" (see Weiss 205) of the "global economy" (Moore 2004; Tsing 2000, 2011), such as local businesses, importers, workers and consumers, were excluded from the state's concerns. 


\section{New Zealand's Quest for Free Trade}

The TPP is a free trade agreement between Australia, Brunei, Canada, Chile, Japan, Malaysia, Mexico, New Zealand, Peru, Singapore, the United States (until 23 January 2017) and Vietnam. After seven years of negotiation, it was finally signed on 4 February 2018. As a founding member of the Agreement, New Zealand has played a critical role from 1997, when it was first floated as an idea by politicians in a Singaporean hotel bar, to its current status as the CPTPP.

In official accounts, economic benefits from improved access to globally significant markets and global value chains are presented as the principle rationale for New Zealand's TPP membership. This commentary is frequently accompanied with benign reference to New Zealand being a "trading nation" and a "small country, distant from important markets". "Trade", we are repeatedly told by the state, is "part of our everyday life" and our "lifeblood". Trade Minster Todd McClay's speech at the signing of the TPP exemplifies this common refrain. He not only reiterated how "We are a small export nation" dependent on trade but also explained that the TPP was about "doing what's right for New Zealanders" because it will "bring prosperity, jobs and higher incomes for your kids and mine" (McClay 2017).

These platitudinous remarks are irrefutable: New Zealand is a comparatively small country, and our economy does indeed rely on exports. But certain questions are omitted in this narrative: Has New Zealand always depended on free trade to "prosper"? How is "prosperity" defined and by whom? When did "trade" become synonymous with "free trade"? In New Zealand's recent history, alternative versions of trade policy existed, but since the mid-1980s, following the introduction of neoliberal reforms, these possibilities have been tacitly, and until protests, successfully, vanquished by the state with the help of business elites in favour of a neoliberal approach.

A year after becoming a British colony in 1840, New Zealand applied its first tariffs (Belich 2001; Hawke 1985). From this date until the late 1970s, the state used trade policy to moderate external problems and demands, generate revenue, bolster employment and grow the agricultural and manufacturing industries. Owing to New Zealand's small population and distance from trans-Atlantic trade routes, active state participation in the economy was considered necessary to foster a capitalist society in the likeness of "Mother England" (Condliffe 1969, Jesson 1987). As Hawke (1985) notes, during this period, there was broad agreement that New Zealand's economy should be "determined less by events overseas and more by the choice of local people" (163).

In the late 1970s, a series of events adversely effected New Zealand's economy. It was at this point that the approach to trade began to shift (Nixon and Yeabsley 2002). In 1973, Britain joined the European 
Economic Community (EEC). With this move, New Zealand lost its preferential market access. This setback coincided with the 1973 oil crisis and resulted in the election of a National government (1975-1984) that borrowed heavily to pay for the construction of large energy projects. Indebted and struggling to find new markets, the New Zealand economy entered its first recession (1976-78, 1982-83). In response, state officials from the most influential government agencies, the Reserve Bank, Treasury, the Prime Minister's Department, and the Ministry of External Relations (MERT), along with the peak farmer organisation Federated Farmers, began to agitate for a change to New Zealand's approach to trade. They argued that the system of subsidies, tariffs, import controls and licencing were a drag on the economy and impaired New Zealand's negotiations at the General Agreement for Tariffs and Trade (GATT). New Zealand, they insisted, couldn't expect the Europeans to open their markets to its products while it maintained its "fortress" of protections. However, proponents were also acutely aware of the difficulties in creating domestic support for policy change. Following the end of the Tokyo Round of GATT negotiations in 1979, in which agriculture was carved out from tariff reductions, Australia approached New Zealand and proposed the formation of an updated trade treaty. This provided the necessary external pressure and pretext for the state to reorganise trade policy. The vision was a trade approach based on neo-classical economics with minimal state intervention (Kelsey 1995).

In 1983, New Zealand signed its first comprehensive FTA, the Closer Economic Partnership agreement with Australia (CER). This agreement was a turning point for New Zealand trade policy and laid the ground for further, more widespread policy reforms. Thus, in 1985, a year after the election of a new Labour government (1984-1990), all tariffs were unilaterally cut and subsidies to farmers were completely removed. Tariff rates above 25 percent were dropped to 5 percent in 1986, and in 1988, a new State Sector Act delinked domestic policy from trade policy. As a result, trade policy that had previously been managed by the Department of Trade and Industry (DTI) was transferred to the newly formed, "outward" facing Ministry for External Relations and Trade (MERT). Woodfield (2009) notes of this change, “... the decision signalled the government's view of New Zealand's international trade as primarily an aspect of foreign policy rather than primarily the international extension of New Zealand's domestic economic policy, which had been the approach over the preceding century" (162).

Until the late 1990s, the public appeared to accept the state's new policy approach. However, in 1999, disinterest gave way to dissent after the election of a left-leaning government and anti-globalisation protests in New Zealand at the Asia Pacific Economic Cooperation (APEC) leaders' summit and in Seattle at the World Trade Organisation (WTO) ministerial meeting. In parliament, the long-serving National Party was defeated by a 
centre-left Labour Government (1999-2008). It formed a majority with coalition partners the democratic socialist Alliance party, which was aligned with the anti-globalisation movement and strongly objected to continuing FTA negotiations with Singapore. With the shift from a centreright to the left and debate about the Singapore FTA, concerns were raised by free trade proponents that the state's trade approach was at risk. This provoked a loose network of state and corporate elites to form new pro-free trade, business-led groups: the APEC Business Group, the NZ-US Council and the Trade Liberalisation Network. In 2001, these groups coordinated the first pro-free trade conference called the "Coalitions of Interest" in Auckland. More than140 business leaders, journalists, diplomats, officials and politicians, including Prime Minister Helen Clark, attended.

Drawing on the support of these new business groups, throughout the 2000s, the state managed to rebuild public support and marginalise opposition. After the Singapore FTA was signed in 2001, successive New Zealand Labour-led and National-led governments signed FTAs with the Association of South East Asian countries (ASEAN) (2004), Thailand (2005), Brunei (2005), Chile (2005), China (2008), Malaysia (2009), Hong Kong (2011), Taiwan (2013) and South Korea (2015). In 2009, the US officially joined the TPP negotiations. The government then stepped up its public diplomacy drive in order to attenuate anti-American sentiment, which had surfaced in New Zealand, and to convince the US that the TPP was strategically significant enough for it to ignore its own opposition voices. Towards this end, the government worked closely with the business-government organisations to circulate messages about the economic benefits of the TPP and to strengthen relations with other TPP states, particularly the US but also Japan. As an example, between 2006 and 2015, the business organisation called the NZ-US Council held a series of closed meetings called the NZ-US Partnership Forum. These meetings, two of which I attended as a researcher $(2009,2011)$ in Washington DC and Auckland, were designed to create and maintain highlevel links between New Zealand and US senior administration, congressional, defence and business leaders.

Despite the government's sustained efforts to persuade the public about the merits of the TPP, protests against it grew more vocal and widespread as negotiations progressed. This opposition focused on the negative outcomes from the negotiation text's 30 chapters and on whose interests the TPP served (Kelsey 2010). The issues varied from distress about job loss and increased income inequality through to the affordability of medicines; foreign ownership and investment rights; weak protections for human rights, public health, labour and the environment; financial deregulation; unsafe food and loss of sovereignty. In New Zealand, frequent protests were organised by activist groups such as It's Our Future and TPP Watch. These groups were part of an activist 
network that spanned the TPP countries and encompassed diverse interests from consumer protection to human rights, environment, academics, unions and civil rights organisations. Protesters focused on their specific sector issues and/or argued for greater transparency and more "meaningful" stakeholder engagement with governments.

In the United States, the Washington-based group Public Citizen was particularly active, leading to successful awareness-raising campaigns that helped to elevate the TPP into a US election issue. First, candidate Bernie Sanders denounced the deal, calling for progressive alternatives, and then followed Hillary Clinton and Donald Trump, who both pledged to scrap the TPP to protect American workers. This culminated into the momentous event on 23 January 2017. In front of a line of cameras, newly elected President Trump signed the Executive Order as promised in his "Contract to the People" 9 and withdrew the United States from the deal.

\section{Rescuing the TPP}

Two months after Trump pulled the US out of the TPP, in April 2017, New Zealand released its new trade strategy: Trade Agenda 2030: Securing Our Place in the World. This was the first strategic document the government had produced since 1993. I was keen to read what changes they were intending to make as a result of Trump's election, the Brexit vote and the general misgivings about free trade. They had chosen to launch the strategy at a breakfast organised by the New Zealand International Business Forum (NZIBF) and the Auckland Chamber of Commerce.

On the morning of the launch, as I entered the room, a foreign affairs official handed me the strategy document, Trade Agenda 2030. Its cover pictured the globe with images depicting a geothermal plant, a laboratory, a sheep farm, a winery, forestry and a fishing vessel surrounding New Zealand. These scenes portrayed New Zealand as innovative and agricultural. In the crowded room mingled the Prime Minister, the Head of Foreign Affairs, the Ministers of Trade and Foreign Affairs (MFAT), chief trade negotiators, high-level officials from the Ministry, business leaders and a few pro-free trade business journalists. I noted the high number of young foreign affairs officials, who sat taking notes diligently throughout the proceedings. I took my seat at the back of the room as the Prime Minister Bill English made his way to the podium.

In his speech, English introduced the government's new trade strategy in the context of a threat, a looming crisis (Roitman 2013) that Trump had come to signify. Both during and after the speech, the business

\footnotetext{
${ }^{9}$ D. Trump “Trump's Contract to the American Voter", 16 November 2016 https://assets.donaldjtrump.com/ landings/contract/0-TRU-102316Contractv02.pdf
} 
and government audience appeared unmoved but seemingly in agreement with English's logic: in the face of rising protectionism, the state must expand not abate the network of FTAs and press on with the TPP without the participation of the US. I present excerpts from his 2017 speech below to highlight the rhetorical moves as it weaves together cultural, liberal and business references in order to reaffirm the state's neoliberal trade approach,

Leaders, entrepreneurs and risk takers. I see people who are backing themselves and their businesses on the world stage and succeeding. New Zealanders who are taking other Kiwis with them and providing jobs and incomes to Kiwi families. New Zealanders who are creating international connections, growing our global reputation and adding value to our country. We all recognise you and your success.

In his opening salutation, English addressed the audience as particular types of economic actors, not as producers, owners, management or exporters per se but as "Leaders, entrepreneurs and risk takers", framing them in a financialised idiom. As noted by Brown (2015), the distinctiveness of neoliberal political rationality is in how it "economises" non-economic spheres, subjects and states. She adds that there has been a recent shift from framing human beings as economic and political actors to "financialised human capitals" (33). This feature of contemporary neoliberalism is evident in English's representations of business as "risk takers" and can also be seen in how he applauded business for "adding value to the country". English then continued to celebrate the audience for their self-reliance ("backing themselves"), selflessness and loyalty in helping to grow the "national economy" (Appel 2017) and "providing jobs" for "Kiwi families". In his remark, we can see the meshing of financial, entrepreneurial references with the colonial myth of the rugged, masculine, European (Bell 1996). Following this praise, English's speech then descended quickly into depicting a bleak future:

The biggest threat to our economic success at the moment is disruption of international trade. New barriers and less integration would do exactly the opposite of what their champions claim. They would mean consumers pay more, have less choice, and the world would be less efficient. There would be fewer jobs, incomes would grow more slowly, and we would make slower progress on challenges we face as an international community. That means less confidence and greater instability. It is a depressingly backward scenario, and there would be no winners.

In his last sentence, English comments that "there would be no winners" without free trade. Free trade, he argues, will help us to overcome the "challenges we face as an international community". What we can infer from this is that "healthy" competition, abetted by FTAs, will 
help solve a myriad of social, political and environmental problems. This statement normalises competition as form of relating between "winners" and "losers" (see Brown 2015), but it also implies that in order to address poverty, inequality, climate change, terrorism and other "challenges", the state's responsibility is to negotiate FTAs and implement policies that will aid, not hinder, comparative advantage. Finally, after crafting this "depressingly backward" scenario, English presents the path forward: to "remain ambitious" and "continue to make the case for free trade":

Free trade has helped spur the strong growth we have seen in our region, made it more stable and lifted millions of people out of poverty. This is part of the reason we were disappointed with decision of the US to withdraw from the TPP. The TPP would have improved regional trade and it would have ensured the US maintained its influence and leadership in the Asia Pacific. Instead it left a vacuum for others to fill. But make no mistake while the US withdrawal is a set-back, it is not the end of the road. Trade negotiations have never been easy. We must remain ambitious and continue to make the case for free trade in a world where opposition has become louder. So I am pleased today to launch the governments' updated trade strategy. Trade Agenda 2030 underlines our ambition to remain a champion of free trade.

English leverages Trump's withdrawal to reposition free trade as history's true moral purpose and asserts that any deviation from this normative order of reason as erroneous and "backward" (see Roitman 2013). Rather than interpret the widespread protests both in New Zealand and other TPP countries as an occasion to question its stance and rethink its policy direction, English instead frames it as a crisis, a sign of a deeper disturbance that leaves no choice but for the state to harden its position. He attempts to incite fear by adding that with US leadership now weakened in the region, "others" will take its place. Although not explicit, "others" represents China. During the TPP negotiations, China was frequently cast as an existential threat to Western liberal democracy, particularly by the United States. ${ }^{10}$

In his closing statement, after expanding on the budget and content of the strategy, including its intentions and aims to "lead on trade, just like we did instigating the TPP", English spoke with nationalistic pride, reaffirming the state's invigorated plan to accelerate its neoliberal approach to trade. English used the common refrain "level the playing field" to make his point and braided together market values with deeply held cultural convictions about the importance of egalitarianism and

${ }^{10}$ On the White House webpage during the Obama administration, for example, a list appeared of consequences if the TPP failed and China wrote the rules of international trade in lieu of the US. These included the erosion of democratic values, workers' rights, human rights, civil liberties and environmental protections. 
fairness:

Ladies and gentlemen, the evidence in favour of free trade is irrefutable. It creates jobs, boosts incomes and prosperity, and it puts us on the world stage. As a government, we are working hard to help create a level playing field for our exporters. And we are incredibly proud seeing New Zealanders succeed. There is so much to gain from advances in free trade. I am committed to seeing those gains, and on behalf of all New Zealanders we will not stop working to achieve them. Thank you.

\section{Defending the State}

As the government's key public diplomacy document detailing its new strategy, Trade Agenda 2030 picks up on themes in English's speech. In the document, not only is the sense of a crisis purposefully exaggerated (Roitman 2013), but free trade is cast as the solution to the concerns raised by protestors and critics. We also see the state classify and treat business people, considered to be active participants in the global economy, differently from other citizens. Whereas the state is in a partnership with business, with other "New Zealanders", the goal is to educate in order to "build confidence and trust in the trade and openness agenda" to therefore "dispel misperceptions about issues such as sovereignty or government's right to regulate for legitimate public policy purposes" (2017:10). Critics' concerns, Trade Agenda 2030 suggests, are misinformed: globalisation, which is distinguishable from free trade and is defined abstractly as "automation", "the changing nature of work", and "improvements to transport and technology", is the real culprit. The "TPP and TTIP"11, we are told, were simply "lightning rods for those concerns". FTAs are neither the root cause nor contributing factor; in fact, FTAs control the runaway effects of globalisation.

To correct critics' ignorance, the document outlines how the state intends to highlight the positive work of FTAs. This involves explaining how free trade can address the "most pressing global problems of our times". FTAs not only "lift millions out of poverty", as English iterated in his opening speech, but in Trade Agenda 2030, we are told they can help protect the environment as well as labour and "... Put simply, success at the trade negotiating table can deliver enhanced agricultural food security, improve livelihoods and developments, as well as contribute to preservation of global fish stocks" (5).This statement is more than a cooptation of protesters' concerns about the detrimental effects of free trade; it subordinates these issues to the imperatives of the economy. In this move, regional economic growth enabled through FTAs has been

\footnotetext{
${ }^{11}$ TTIP is the "Transatlantic Trade and Investment Partnership", an FTA between the US and Europe.
} 
redefined as the means through which global social and environmental concerns can now be met. This undermines the need for specific domestic policies and international treaties to address these problems along with non-trade related governance organisations.

In Trade Agenda 2030, with business, the state is straightforward in its demands. Identified and applauded as active not passive contributors to the economy, business leaders are expected to "translate market access" into "competitive success" and "grow their capacity to engage with government" to "succeed overseas" (46). In return for developing the national economy, the state's commitment to business is to help "facilitate" this process by signing more FTAs. As English stated in his introduction to the new strategic document, "If we open doors, New Zealanders will walk through them, creating opportunities for themselves and others."

But business leaders are not only expected to succeed and provide for the nation. The state also asks them to work harder to defend its policy in the face of opposition from other New Zealanders. In November 2016, on the eve of Trump's election and following Brexit, Trade Minister Todd McClay spoke to the pro-free trade think tank Policy Exchange in London. In his speech titled "The Case for Global Trade in An Era of Populist Protectionism", McClay starts by praising his government's handling of TPP protestors, whom he dismisses as being unenlightened "populists" (see Gusterson 2017). He ends by calling on business to promote free trade:

At the signing of the TPP, 10,000 people marched in protest. Not all of them knew why they were there. That doesn't sound like many, but proportionally that's 1.6 million in the EU. At the final reading of the TPP, only 20 protestors took part. In part that is because we engaged more widely. We talked, explained, fronted up. But governments can't do this alone. We need to find ways to engage with business and industry better, we need them to advocate for the benefit of trade. We need workers whose livelihoods depend on access to foreign markets to see opportunities not threats. In a world increasingly ruled by sound bites, telling these positive stories should be a priority we are unashamed to deliver.

Business elites close to the state have also turned to business in the effort to restore public support for free trade. Take, for example, Phil O'Reilly's post ${ }^{12}$ on the New Zealand International Business Forum's (NZIBF) public diplomacy website "Trade Works". ${ }^{13}$ In his remarks, O’Reilly, New Zealand's representative to the APEC Business's Advisory Committee (ABAC), draws on a crisis trope in the same manner as English

${ }^{12}$ P. O'Reilly. "Talking Trade in Canada”. Trade Works Blog (blog), 4 August 2017 http://www.tradeworks.org.nz/?p=2702

${ }^{13}$ See http://www.tradeworks.org.nz/, accessed 31 August 2017 
and Trade Agenda 2030 in order to encourage business to defend free trade. Adopting a political-military register, he urges business to wake up from complacency and become more proactive for the sake of "our communities":

These are testing times for trade liberalisation. There has been a lot of talk over the last year about the rise of protectionism and the risks of an all-out trade war. Whether this actually manifests in significant concrete action remains to be seen - but what should worry us is how hard it is to shift the dial on the public debate on trade. We cannot afford to be disengaged from this: our communities (and the most vulnerable groups in them) will be the losers if we see the erosion of a fifty-year consensus towards more open markets and freeing up flows of trade, investment and people.

O'Reilly is not the only member of the business elite to mimic the state and responsibilise business. Stephanie Honey, Associate Director of the New Zealand International Business Forum (NZIBF), exemplifies this narrative. In her blog 14 on Trade Works she attempts to provoke business into action by calling on them to rise up as a team of "Globalists" and stop the deluded economic nationalists from leading the world into catastrophe. Her message is similar to English's and draws on modernist notions to cast free trade as progressive and other versions as dangerously antediluvian,

For Globalists, this is a dispiriting time with a swing towards economic nationalism and ceding of global economic leadership by the Trump Administration. Political and business leaders must continue to champion greater openness and talk about the real benefits of globalisation. They [protectionists] must recognise they cannot roll back the clock and indeed trying to do so would be catastrophic for the world economy and for their own communities.

\section{Conclusion}

In New Zealand, free trade is far from dead. Before the demise of the TPP, the state had entreated business to utilise trade agreements and selectively drew on the resources of an elite business-government network to help support this message. This strategy had worked in favour of the constrained neoliberal state by helping to create the appearance of a broad consensus within New Zealand and to foster relationships with counter-party elites in other pro-free trade countries. However, when confronted by overwhelming opposition and the likely withdraw of the US, rather than reconsider its stance on trade, the state deployed discursive strategies and sought additional help from business in order to

\footnotetext{
${ }^{14}$ S. Honey. "Defending Globalisation: We're all in this Together". Trade Works Blog (blog), 17 April 2017, http://www.tradeworks.org.nz/?p=2566
} 
defend and promote free trade and the TPP. Thus, Trump's decision was reframed as a crisis that threatened Western liberal democracy ("our way of life"), and free trade, primed as the enabler of economic growth, was recast as the solution to, rather than the cause of, public concerns. In its place were positioned the impersonal, unassailable forces of globalisation. Valued by the state as active participants in the global economy, business leaders were doubly responsibilised: both expected to succeed as patriotic "risk takers" with minimal state assistance and called on to halt the rise of "populist protectionism" for the sake of not only the nation ("Kiwi families") and the "most vulnerable" but also the entire "international community".

The implications of this manoeuvre are stark. With business enjoined to act like a state and the state to behave like a firm, responsibilities are reshuffled and the fate of the national economy and the people rests with unelected management and boards whose primary commitment is to maximise profit, not public welfare. Meanings are also altered as non-economic concepts such as justice and fairness are drawn on to mobilise support in what Colin Crouch has described as the weakness of neoliberalism: its inability to become a popular political force because of its overly detailed, technical ideas, which are "remote from human experiences" (see Crouch 2016: 499). Free trade, when codified by law as FTAs, enshrines these types of transpositions. Moreover, contemporary versions of FTAs, such as the TPP, which explicitly seek to include sustainability and development chapters, transform FTAs into legally sanctioned CSR policies and standards writ large. This expansion raises a number of issues. Most significant is the elevation of economic growth as the singular critical path to addressing non-economic issues and the usurpation of state-led development by business as the principal organising agent (Rajak 2011). Related to this is the undermining of enforceable state policies and intergovernmental treaties by weaker, softer FTA rules. Thus new trade agreements such as the TPP provide business with the credibility and moral legitimacy of being socially responsible (see Foster 2014; Rajak 2011) without the costs or liability of implementation.

The observations made in this case study about the transpositioning of business and government is the result of long term fieldwork starting in 2009. At first glance, it would appear that business agitates the state to pursue free trade agreements. However with closer analysis over a long duration what is revealed is the stronger hand of the state to determine policy direction, shape rhetoric and selectively decide who should be chosen as 'partners'. Policy affects business, and international trade agreement such as the TPP, can have lasting effects on the ways of doing business. It is therefore important for researchers to both pay detailed attention to the making of policy and question assumptions about the power of business, but also to consider the 
cultural contexts in which policy enfolds. In the case of the TPP in New Zealand, business may have fronted the free trade discourse but working actively from behind was the state.

\section{References}

Appel, H. 2017. Toward an ethnography of the National Economy. Cultural Anthropology, 32(2): 294-322. https://doi.org/10.14506/ca32.2.09

Besky, S. 2016. The Darjeeling distinction: Labor and justice on fair-trade tea plantations in India. Oakland, CA: University of California Press.

Bell, Claudia. 1996. Inventing New Zealand: Everyday myths of Pakeha identity. Wellington: Penguin Books.

Belich, J. 2001. Making peoples: A history of the New Zealanders, from Polynesian settlement to the end of the nineteenth century. Honolulu: University of Hawaii Press.

Berman, M., and J. Johnson. 1977. Unofficial diplomats. New York: Columbia University Press.

Bourdieu, P., and T. Eagleton. 1992. Doxa and common life. New Left Review, 191(1):111-21.

Brawley, M. R. 2005. Power, money and trade: Decisions that shape global economic relations. Toronto: Broadview Press.

Brown, W. 2015. Undoing the demos: Neoliberalism's stealth revolution. Michigan: MIT Press.

Çalışkan, K., and M. Callon. 2009. Economization, part 1: Shifting attention from the economy towards processes of economization. Economy and Society, 38(3): 369-398. https://doi.org/10.1080/03085140903020580

Çalışkan, K., and M. Callon. 2010. Economization, part 2: a research programme for the study of markets. Economy and Society, 39(1): 1-32. https://doi.org/10.1080/03085140903424519

Crouch, C., D.D. Porta, D.D. and W. Streeck. 2016. Democracy in neoliberalism?. Anthropological Theory, 16(4): 497-512. https://doi.org/10.1177/1463499616677904

Cruikshank, B. 1993. Revolutions within: Self-government and selfesteem. Economy and Society 22(3): 327-44.

https://doi.org/10.1080/03085149300000022 
Comaroff, J. and J. Comaroff. 2009. Ethnicity, inc. Chicago: University of Chicago Press.

https://doi.org/10.7208/chicago/9780226114736.001.0001

Condliffe, J. B. 1969. The economic outlook of New Zealand. Christchurch: Whitcombe and Tombs.

Cox, R., ed. 1996. Business and the state in international relations. Oxford: Westview Press.

Dolan, C. and Rajak, D. eds., 2016. The anthropology of corporate social responsibility. Oxford: Berghahn Books.

English, B. "PM Launches Ambitious Trade Agenda". Speech given at New Zealand's updated trade strategy Trade Agenda 2030, New Zealand, 24 March, 2017.

Evans, L., and M. Richardson. 2002. Trade reform in New Zealand: Unilateralism at work. In Going alone: the case for relaxed reciprocity in freeing trade. J. Bhagwati, ed. Pp 167-217. Cambridge, MA: MIT Press.

Feldman, G. 2005. Culture, state, and security in Europe: The case of citizenship and integration policy in Estonia. American Ethnologist, 32(4): 676-94. https://doi.org/10.1525/ae.2005.32.4.676

Feldman, G. 2011. Illuminating the apparatus: Steps toward a nonlocal ethnography of global governance. In Policy worlds: anthropology and the analysis of contemporary power. C. Shore, S. Wright and D. Pero, eds. Pp 32-49. Oxford: Berghahn Books.

Fisher, J. 2013. Fair or balanced?: The other side of fair trade in a Nicaraguan sewing cooperative. Anthropological Quarterly 86(2): 527557. https://doi.org/10.1353/anq.2013.0017

Foucault, M. 1978/1991. Governmentality. In The Foucault effect: studies in governmentality. G. Burchell, C. Gordon and P. Miller, eds. Pp 87-104. Chicago: University of Chicago Press.

Garsten, C., and M. Montoya, eds. 2008. Transparency in a new global order. Cheltenham: Edward Elgar Publishing. https://doi.org/10.4337/9781848441354

Gledhill, J. 1995. Neoliberalism, transnationalization, and rural poverty: a case study of Michoacán, Mexico. Boulder, CO: Westview Press.

Greenhalgh, S. 2008. Just one child: Science and policy in Deng's China. California: University of California Press. https://doi.org/10.1525/california/9780520253384.001.0001 
Grossman, G., and E. Helpman. 2002. Interest groups and trade policy. Princeton, NJ: Princeton University Press.

Griffith, M.K., R. Steinberg and J. Zysman. 2015. Great power politics in a global economy: Origins and consequences of the TPP and TTIP. http://www.brie.berkeley.edu/wp-content/uploads/2015/02/GreatPower-Politics-in-a-Global-Economy-Origins-and-Consequences-of-theTPP-and-TTIP.pdf.

Gusterson, H. 2017. From Brexit to Trump: Anthropology and the rise of nationalist populism. American Ethnologist 44(2): 209-214. https://doi.org/10.1111/amet.12469

Gutmann, M. C. 1978. For whom the taco bells toll: Popular responses to NAFTA south of the border. Critique of Anthropology 18(3): 297-315. https://doi.org/10.1177/0308275X9801800305

Hawke, G. 1985. The making of New Zealand: An economic history. Cambridge: Cambridge University Press.

Hastrup, K. 2005. Social anthropology: towards a pragmatic enlightenment. Social Anthropology 13(2): 133-149.

https://doi.org/10.1017/S0964028205001199

Hewamanne, S. 2008. Stitching identities in a free trade zone: Gender and politics in Sri Lanka. Philadelphia, PA: University of Pennsylvania Press. https://doi.org/10.9783/9780812202250

Hoffman, L. 2010. Patriotic professionalism in urban China: Fostering talent (Vol. 66). Philadelphia, PA: Temple University Press.

Holmes, D.R., 2009. Economy of words. Cultural Anthropology 24(3): 381419.

https://doi.org/10.1111/j.1548-1360.2009.01034.x

Keck, M.E., and K. Sikkink, K. 2014. Activists beyond borders: Advocacy networks in international politics. Ithaca, NY: Cornell University Press.

Kelsey, J. 1995. The New Zealand experiment: a world model for structural adjustment? Auckland: Auckland University Press.

https://doi.org/10.7810/9781869401306

Kelsey, J. 2008. Serving whose interests? The political economy of trade in services agreements. New York: Routledge. https://doi.org/10.4324/9780203933930

Kelsey, J., ed. 2010. No ordinary deal: unmasking the Trans-Pacific Partnership free trade agreement. Wellington: Bridget Williams Books. https://doi.org/10.7810/9781877242502

Krasner, S. 1978. Defending the national interest. Princeton: Princeton 
University Press.

Krasner, S. 2009. Power, the state, and sovereignty: Essays on international relations. New York: Routledge. https://doi.org/10.4324/9780203882139

Krueger, A. 1995. American trade policy: a tragedy in the making. Washington DC: The AEI Press.

Krugman, P. 1986. Strategic trade policy and the new international economics. Cambridge: MIT Press.

Jesson, B. 1987. Behind the mirror glass: the growth of wealth and power in New Zealand in the eighties. Auckland: Penguin Press.

Larner, W. 2003. Neoliberalism: Policy, ideology, governmentality. Studies in Political Economy 63: 5-25 https://doi.org/10.1080/19187033.2000.11675231

Larner, W. 2007. Expatriate experts and globalising governmentalities: the New Zealand diaspora strategy. Transactions of the Institute of British Geographers 32(3): 331-345. https://doi.org/10.1111/j.1475-5661.2007.00261.x

Lea, T. 2008. Bureaucrats and bleeding hearts: Indigenous health in Northern Australia. UNSW Press.

Lewis, M. 2005. The free trade agreement paradox. New Zealand Universities Law Review 21: 554-574.

Li, T.M., 2007. The will to improve: Governmentality, development, and the practice of politics. Durham: Duke University Press https://doi.org/10.1215/9780822389781

Lim, C.L., D.K. Elms and P. Low, eds. 2012. The trans-pacific partnership: a quest for a twenty-first century trade agreement. Cambridge: Cambridge University Press. https://doi.org/10.1017/CB09781139236775

Lyon, S. 2010. Coffee and community: Maya farmers and fair-trade markets. Boulder, CO: University Press of Colorado.

McClay, T. "Trans-Pacific Partnership (TPP) Agreement Ministerial Statement. Press release, New Zealand, 17 August, 2017.

McClay, T. "The Case for Global Trade in an Era of Populist Protectionism: Lessons from New Zealand." Speech given at the Policy Exchange, London, 30 November, 2016.

McClay, T. "Todd McClay: A Cause to Celebrate". Speech given at the signing of the TPP, New Zealand, 4 February, 2016. 
Maher, S. 2016. Behind closed doors: Secrecy and transparency in the Trans-Pacific Partnership trade negotiations. SITES: Journal of Social Anthropology and Cultural Studies, 16(2): 187-209

https://doi.org/10.11157/sites-vol13iss2id324

Miyazaki, H., and A. Riles. 2005. Failure as an Endpoint. New Jersey: Blackwell Publishing Ltd.

Moberg, M. 2016. Market's end: Fair-trade social premiums as development in Dominica. American Ethnologist 43(4): 677-690. https://doi.org/10.1111/amet.12383

Milner, H. 1997. Interests, institutions, and information: domestic politics and international relations. Princeton: Princeton University Press Ministry of Foreign Affairs and Trade. 1993. New Zealand trade policy: Implementation and directions, a multitrack approach. Wellington: Ministry of Foreign Affairs and Trade.

Ministry of Foreign Affairs and Trade. 2017. Trade agenda 2030: Securing our place in the world. Wellington: Ministry of Foreign Affairs and Trade.

Mitchell, T. 1999. Society, economy, and the state effect. In State/culture: state formation after the cultural turn. G. Steinmetz, ed. Pp 76-97. Ithaca: Cornell University Press.

Moore, H.L. 2004. Global anxieties: concept-metaphors and pretheoretical commitments in anthropology. Anthropological theory, 4(1):71-88.

https://doi.org/10.1177/1463499604040848

Nader, L. 1972. Up the anthropologist: Perspectives gained from studying up. In Reinventing anthropology. D. Hymes, ed. Pp 284-311. New York: Pantheon Press.

Nixon, C.G. and J. Yeabsley. 2002. New Zealand's trade policy odyssey: Ottawa, Via Marrakech, and on. Wellington: NZIER.

Olson, M. 1965. The logic of collective action. Cambridge, MA: Harvard University Press.

Ong, A. 2006. Neoliberalism as exception: Mutations in citizenship and sovereignty. Durham: Duke University Press. https://doi.org/10.1215/9780822387879

Ong, A. 2007. Neoliberalism as a mobile technology. Transactions of the Institute of British Geographers 32(1): 3-8.

https://doi.org/10.1111/j.1475-5661.2007.00234.x

Pearson, T.W. 2013. "Life is not for sale!": Confronting free trade and intellectual property in Costa Rica. American Anthropologist 115(1): 5871. 
https://doi.org/10.1111/i.1548-1433.2012.01535.x

Petri, P., and M. Plummer. 2012. The Trans-Pacific Partnership and AsiaPacific integration: a quantitative assessment. Peterson Institute for International Economics: Washington D.C.

Putnam, R. 1988. Diplomacy and domestic politics: the logic of two-level games. International Organization 42: 427-460. https://doi.org/10.1017/S0020818300027697

Riles, A. 2004. Real time: Unwinding technocratic and anthropological knowledge. American ethnologist, 31(3): 392-405.

https://doi.org/10.1525/ae.2004.31.3.392

Roitman, J. 2013. Anti-crisis. Durham: Duke University Press. https://doi.org/10.1215/9780822377436

Rose, N., 1999. Powers of freedom: Reframing political thought.

Cambridge: Cambridge university press. https://doi.org/10.1017/CB09780511488856

Schattschneider, E. E. 1935. Politics, pressures and the tariff: a study of free enterprise in Pressure politics as shown in the 1929-1930 revision of the tariff. New York: Prentice-Hall.

Schwegler, T.A. 2008. Take it from the top (down)? Rethinking neoliberalism and political hierarchy in Mexico. American Ethnologist 35(4): 682-700.

https://doi.org/10.1111/j.1548-1425.2008.00105.x

Shore, C., and S. Nugent, eds. 2002. Elite cultures: anthropological perspectives. London: Routledge.

Shore, C., and S. Wright. 1997. Anthropology of policy: Critical perspectives on governance and power. London: Routledge.

Shore, C., S. Wright and D. Però, eds. 2011. Policy worlds: Anthropology and the analysis of contemporary power (Vol. 14). Oxford: Berghahn Books.

Skocpol, T. 1985. Bringing the state back in: Strategies of analysis in current research. In Bringing the state back in. P. Evans, D. Rueschemeyer and T. Skocpol, eds. Pp 3-43. Cambridge: Cambridge University Press. https://doi.org/10.1017/CB09780511628283.002

Slocum, K. 2006. Free trade and freedom: Neoliberalism, place, and nation in the Caribbean. Ann Arbor, MI: University of Michigan Press. https://doi.org/10.3998/mpub.167836

Smith, J. and Helfgott, F., 2010. Flexibility or exploitation? Corporate social responsibility and the perils of universalization. Anthropology Today, 
26(3)": 20-23.

https://doi.org/10.1111/j.1467-8322.2010.00737.x

State Sector Act 1988 (New Zealand).

Tsing, A. 2011. Friction: An ethnography of global connection. Princeton, NJ: Princeton University Press.

Tsing, A. 2000. The global situation. Cultural anthropology, 15(3): 327360.

https://doi.org/10.1525/can.2000.15.3.327

Wedel, J. 2004. Blurring the state-private divide: flex organisations and the decline of accountability. In Globalization, poverty and conflict: a critical development reader. M. Spoor, ed. Pp 217-235. Boston: Kluwer Academic Publishers.

Wedel, J. 2009. Shadow elite: how the world's new power brokers undermine democracy, government and the free market. New York: Basic Books.

Welker, M.A., 2009. "Corporate security begins in the community": Mining, the corporate social responsibility industry, and environmental advocacy in Indonesia. Cultural Anthropology, 24(1): 142-179. https://doi.org/10.1111/i.1548-1360.2009.00029.x

Woodfield, T. 2009. Trade negotiations: punching above our weight. In Agents abroad: the story of the New Zealand Trade Commissioner Service. New Zealand Trade and Enterprise. Pp 137-164. Auckland: Penguin.

Wright, S., and S. Reinhold. 2011. "Studying through": a strategy for studying political transformation. Or sex, lies and British politics. In Policy worlds: anthropology and the analysis of contemporary power. C. Shore, S. Wright and D. Pero, eds. Pp 86-104. Oxford: Berghahn Books.

Sasha Maher, Ph.D. is a Research Fellow at the Anthropology Department, and Mira Szaszy Centre for Maori and Pacific Development at the University of Auckland. Sasha's research addresses trade politics, small states, business-government relations, and corporate social responsibility. Her email address is s.maher@auckland.ac.nz. 